\title{
Prevention of Flavobacterium psychrophilum Vertical Transmission by lodophor Treatment of Unfertilized Eggs in Salmonids
}

\author{
Akira Kumagai $^{1 *}$ and Akatsuki Nawata ${ }^{2}$ \\ ${ }^{1}$ Miyagi Prefecture Fisheries Technology Institute, Miyagi 986-2135, Japan \\ ${ }^{2}$ Miyagi Prefecture Fisheries Technology Institute Freshwater Fisheries \\ Experimental Station, Miyagi 981-3625, Japan
}

(Received July 5, 2010)

\begin{abstract}
We evaluated the efficacy of povidone-iodine treatments in preventing vertical transmission of Flavobacterium psychrophilum in the eggs of masu salmon Oncorhynchus masou, Japanese char Salvelinus pluvius, coho salmon $O$. kisutch and rainbow trout $O$. mykiss. When newly spawned eggs were immersion-challenged with F. psychrophilum (>10 $\mathrm{CFU} / \mathrm{mL})$ and subsequently disinfected with povidone-iodine (50 ppm in PBS, $15 \mathrm{~min}$ ) prior to fertilization, the pathogen was not detected in the contents of the eggs. Without this pre-fertilization disinfection with povidone-iodine, however, procedures such as water-hardening of immersion-challenged eggs in povidone-iodine (50-100 ppm in water) and rinsing of the F. psychrophilum-contaminated eggs with PBS were insufficient to control the intraovum infection. In a separate experiment using coho salmon eggs challenged with F. psychrophilum, pre-fertilization disinfection was effective to prevent bacterial cold-water disease in the produced fry. Surface disinfection of unfertilized eggs immediately after spawning is thus essential to prevent vertical transmission of F. psychrophilum.
\end{abstract}

Key words: vertical transmission, Flavobacterium psychrophilum, bacterial cold-water disease, povidone-iodine, salmonid egg, BCWD

Flavobacterium psychrophilum is the causative agent of bacterial cold-water disease (BCWD) (Holt et al., 1993) and rainbow trout fry syndrome (Bernardet and Kerouault, 1989), which affects salmonids ranging from yolk-sac to yearling fish worldwide (Nematollahi et al., 2003). Outbreaks of BCWD have occurred in coho salmon Oncorhynchus kisutch hatcheries since the middle of the 1980s in Japan (Wakabayashi et al., 1991), and the disease is a serious problem in the aquaculture of other salmonids such as rainbow trout O. mykiss, masu salmon O. masou and Japanese char Salvelinus pluvius (Aoshima, 2007).

Brown et al. (1997) and Cipriano (2005) demonstrated that F. psychrophilum was transmitted within salmonid eggs by cultivating naturally infected eggs, indicating that iodophor treatment of eyed eggs, which has been previously recommended to prevent transmission of the pathogen on the egg surface, did not always prevent BCWD in subsequent fry. Thus, the vertical transmission of F. psychrophilum via intra-ovum infection appears to lead to the spread of BCWD among hatcheries with the delivery and transportation of con-

\footnotetext{
* Corresponding author

E-mail: kumagai-ak557@pref.miyagi.jp
}

taminated eggs, resulting in serious adverse effects on the aquaculture of salmonids.

F. psychrophilum has been detected in the ovarian fluid of sexually mature salmonids (Holt et al., 1993). Our previous study (Kumagai and Nawata, 2010) demonstrated that intra-ovum infection occurred in eggs obtained from females with a high bacterial load in the ovarian fluid, suggesting that the bacteria in the ovarian fluid contaminated the surfaces of eggs and passively entered eggs during water-hardening. In the study, a possibility that the povidone-iodine treatment prior to fertilization could effectively prevent intra-ovum infection by $F$. psychrophilum was also suggested. The present study was conducted to ascertain whether vertical transmission of F. psychrophilum could be controlled by disinfecting experimentally contaminated unfertilized eggs with povidone-iodine prior to fertilization.

\section{Materials and Methods}

\section{Bacterium}

F. psychrophilum strain FPC828 was used to artificially infect eggs. This strain was isolated from the kidneys of coho salmon fry from Miyagi Prefecture, Japan, in 1990 (Wakabayashi et al., 1991). The bacteria were 
cultivated in $300 \mathrm{~mL}$ of a modified Anacker and Ordal's broth (tryptone $0.3 \%$, yeast extract $0.2 \%$, beef extract $0.02 \%$, sodium acetate $0.02 \%, \mathrm{pH} 7.2$ ) at $15^{\circ} \mathrm{C}$ for 3 days. F. psychrophilum cells were collected by centrifugation $\left(1,660 \times g\right.$ for $15 \mathrm{~min}$ at $\left.4^{\circ} \mathrm{C}\right)$, rinsed three times with sterile phosphate-buffered saline (PBS), and then re-suspended in $30 \mathrm{~mL}$ of sterile PBS.

\section{Treatment with povidone-iodine for prevention of intra-ovum infection}

Eggs and milt were obtained from mature masu salmon (> 2-years-old), which had been kept at the Miyagi Prefecture Fisheries Technology Institute Freshwater Fisheries Experimental Station (MFTIFFES). Pooled eggs collected from 15 females were rinsed three times with sterile PBS and divided into eight lots each consisting of approximately 500 eggs in $250 \mathrm{~mL}$ conical flasks. Table 1 summarized manipulations in each experimental lot. For the egg challenge, $2 \mathrm{~mL}$ of the F. psychrophilum cell suspension $\left(2.3 \times 10^{9}\right.$ $\mathrm{CFU} / \mathrm{mL}$ ) was added to seven of the eight egg lots (lots $\# 1-\# 7$ ), and gently agitated. A $2 \mathrm{~mL}$ volume of sterile PBS was added to the remaining egg lot (lot \#8), as a control. In lot \#1, the challenged eggs were immediately dry-fertilized with $0.7 \mathrm{~mL}$ of milt pooled from five males and then were water-hardened for $45 \mathrm{~min}$ in 180 $\mathrm{mL}$ of $F$. psychrophilum-free water. For lot \#2, the challenged eggs were disinfected with povidone-iodine (50 ppm in PBS, $15 \mathrm{~min}$ ) prior to fertilization and rinsed three times with $180 \mathrm{~mL}$ of sterile PBS. Following disinfection, the eggs were inseminated and then waterhardened in $180 \mathrm{~mL}$ of water. In lots \#3 and \#4, after having carried out the same manipulations of disinfection and insemination as in lot \#2, the fertilized eggs were water-hardened in $180 \mathrm{~mL}$ of povidone-iodine at 50 ppm and 100 ppm, respectively. In lot \#5, the challenged eggs were rinsed three times in five egg volumes of sterile PBS instead of povidone-iodine treatment, and then inseminated and water-hardened. The challenged eggs in lots \#6 and \#7 were immediately inseminated without disinfection or rinsing, and were water-hardened in povidone-iodine at 50 ppm and 100 ppm, respectively. The eggs in lot \#8, which were unchallenged, were inseminated and water-hardened. Following water-hardening, all egg lots were disinfected with $50 \mathrm{ppm}$ povidone-iodine $(180 \mathrm{~mL})$ for $15 \mathrm{~min}$. After this treatment, each lot of eggs was discretely incubated at $8 \pm 1^{\circ} \mathrm{C}$ on a tray within a $5 \mathrm{~L}$ aquarium with flow-through water at an approximate flow rate of 0.5 $\mathrm{L} / \mathrm{min}$. Dead eggs were removed from the aquaria once a week to prevent fungal disease.

The challenged eggs were examined for intra-ovum infection by F. psychrophilum at 37 days post-challenge. Sixty live eyed eggs were collected from each lot and disinfected with $50 \mathrm{ppm}$ povidone-iodine for $15 \mathrm{~min}$ to kill bacteria on the egg surface. Each egg was placed in a sterile tube and was then homogenized with a sterile rod. The homogenate was spread on an enriched Anacker and Ordal's agar plate (Lorenzen and Karas, 1992) with a cotton swab. The plates were incubated at $15^{\circ} \mathrm{C}$ for 7 days. Identification of the isolated $F$. psychrophilum was made by indirect fluorescent antibody technique (IFAT) using an antiserum against $F$. psychrophilum FPC828, according to the method described by Kumagai et al. (1998). The antiserum was provided from the University of Tokyo. After sampling 60 live eggs, the number of remaining live eggs in each lot was counted for eyed-egg rates.

Japanese char (> 2-years-old), coho salmon (> 2years-old) and rainbow trout (> 3-years-old) which had been kept at MFTIFFES were also used in experiments, in the same manner as described above. Each lot of Japanese char, coho salmon and rainbow trout consisted of 640,450 and 700 eggs, respectively. The challenge dose was $7.1 \times 10^{9}, 1.9 \times 10^{9}$ and $2.2 \times 10^{9}$ $\mathrm{CFU} / \mathrm{mL}$, and bacteriological examination at the eyed egg stage was undertaken at 41,37 and 28 days postchallenge, respectively.

Table 1. Summary of manipulations performed on masu salmon, Japanese char, coho salmon and rainbow trout eggs in experiment of the efficacy of povidone-iodine treatments in preventing intra-ovum infection of Flavobacterium psychrophilum

\begin{tabular}{ccccc}
\hline Lot No. & $\begin{array}{c}\text { Immersion challenge of } \\
\text { eggs with } \\
\text { F. psychrophilum }\end{array}$ & $\begin{array}{c}\text { Egg treatment prior to } \\
\text { fertilization with }\end{array}$ & $\begin{array}{c}\text { Water-hardening of eggs } \\
(45 \text { min) with }\end{array}$ & $\begin{array}{c}\text { Disinfection of water- } \\
\text { hardened egg with } \\
\text { povidone-iodine } \\
(50 \text { ppm, } 15 \text { min })\end{array}$ \\
\hline 1 & Yes & No & Water & Yes \\
2 & Yes & Povidone-iodine $(50 \mathrm{ppm})$ & Water & Yes \\
3 & Yes & Povidone-iodine $(50 \mathrm{ppm})$ & Povidone-iodine $(50 \mathrm{ppm})$ & Yes \\
4 & Yes & Povidone-iodine $(50 \mathrm{ppm})$ & Povidone-iodine $(100 \mathrm{ppm})$ & Yes \\
5 & Yes & PBS & Wovidone-iodine $(50 \mathrm{ppm})$ & Yes \\
6 & Yes & No & Povidone-iodine $(100 \mathrm{ppm})$ & Yes \\
7 & Yes & No & Water & Yes \\
\hline
\end{tabular}


Treatment of unfertilized coho salmon eggs with povidone-iodine for prevention of transmission to fry

Pooled unfertilized coho salmon eggs obtained from ten females were divided into eight lots each consisting of approximately 1,000 eggs. Seven of the eight lots were challenged with bacteria $\left(7.0 \times 10^{7}\right.$ $\mathrm{CFU} / \mathrm{mL}$ ) in the same manner as above. Five of the challenged egg lots were disinfected with povidoneiodine (50 ppm in PBS, $15 \mathrm{~min}$ ), and rinsed three times with sterile PBS. These five disinfected egg lots were each fertilized with $0.7 \mathrm{~mL}$ of pooled milt from five males and then water-hardened for $45 \mathrm{~min}$ in $180 \mathrm{~mL}$ of povidone-iodine at various concentrations of 50, 100, 150 and 200 ppm (lot \#1-\#4), or F. psychrophilum-free water (lot \#5), respectively. One egg lot of the remaining two challenged lots was rinsed three times with five egg volumes of sterile PBS instead of povidone-iodine treatment (lot \#6), while the other egg lot was neither disinfected nor rinsed (lot \#7). Both of these lots were inseminated and water-hardened. One uninfected lot was inseminated and water-hardened as a control (lot \#8). Following water-hardening, all of the egg lots were disinfected with povidone-iodine (50 ppm, $15 \mathrm{~min}$ ) and discretely incubated in flow-through water in the same manner as described above.

On day 37 post-challenge, 60 live eyed eggs from each of the eight lots were examined for F. psychrophilum intra-ovum infection according to the same method as above. Furthermore, 300 live eggs from each lot were transferred into $20 \mathrm{~L}$ aquaria just prior to hatching. The fry originating from each lot were discretely reared in these aquaria at $8 \pm 1^{\circ} \mathrm{C}$ with flowing water $(0.5$ $\mathrm{L} / \mathrm{min}$ ) for six months with a commercial diet. For bacterial isolation, the kidney tissues of the moribund fry were inoculated on the enriched Anacker and Ordal's agar plate during the rearing period. The hatching rates in each lot and the survival rates of the fry were also examined.

\section{Results}

The efficacy of povidone-iodine treatments in preventing intra-ovum infection

We obtained similar results in every trial with four salmonid species. F. psychrophilum was isolated from egg lots in which the challenged eggs were immediately inseminated without disinfection prior to fertilization and then water-hardened (lot \#1). The prevalence of $F$. psychrophilum in eggs from these lots ranged from $5 \%$ $(3 / 60)-17 \%(10 / 60)$ (Table 2). In contrast, when the challenged eggs were disinfected with povidone-iodine prior to fertilization and subsequently water-hardened in water (lot \#2) or povidone-iodine (lots \#3 and \#4), the eggs proved to be pathogen-free. When the challenged eggs were rinsed with PBS (lot \#5) without iodine treatment prior to fertilization, the prevalence of
Table 2. Detection of Flavobacterium psychrophilum from the content of bacterial-challenged eggs of four salmonid fishes in different treatment with povidone-iodine

\begin{tabular}{|c|c|c|c|}
\hline Fish & Lot No. ${ }^{* 1}$ & $\begin{array}{l}\text { Intra-ovum } \\
\text { infection rate }\end{array}$ & $\begin{array}{r}\text { Eyed-egg } \\
\text { rate (\%) }\end{array}$ \\
\hline \multirow{8}{*}{ Masu salmon } & 1 & $3 / 60 * 2$ & 89.1 \\
\hline & 2 & $0 / 60$ & 81.9 \\
\hline & 3 & $0 / 60$ & 84.5 \\
\hline & 4 & $0 / 60$ & 83.7 \\
\hline & 5 & $1 / 60$ & 86.1 \\
\hline & 6 & $1 / 60$ & 82.7 \\
\hline & 7 & $0 / 60$ & 83.0 \\
\hline & 8 & $0 / 60$ & 86.6 \\
\hline \multirow{8}{*}{ Japanese char } & 1 & $8 / 60$ & 82.4 \\
\hline & 2 & $0 / 60$ & 75.1 \\
\hline & 3 & $0 / 60$ & 80.3 \\
\hline & 4 & $0 / 60$ & 83.2 \\
\hline & 5 & $10 / 60$ & 76.0 \\
\hline & 6 & $2 / 60$ & 70.3 \\
\hline & 7 & $1 / 60$ & 85.1 \\
\hline & 8 & $0 / 60$ & 76.9 \\
\hline \multirow{8}{*}{ Coho salmon } & 1 & $10 / 60$ & 69.9 \\
\hline & 2 & $0 / 60$ & 77.8 \\
\hline & 3 & $0 / 60$ & 75.2 \\
\hline & 4 & $0 / 60$ & 78.9 \\
\hline & 5 & $8 / 60$ & 76.7 \\
\hline & 6 & $0 / 60$ & 70.6 \\
\hline & 7 & $1 / 60$ & 75.0 \\
\hline & 8 & $0 / 60$ & 70.5 \\
\hline \multirow{8}{*}{ Rainbow trout } & 1 & $6 / 60$ & 73.6 \\
\hline & 2 & $0 / 60$ & 79.4 \\
\hline & 3 & $0 / 60$ & 72.7 \\
\hline & 4 & $0 / 60$ & 69.8 \\
\hline & 5 & $11 / 60$ & 66.4 \\
\hline & 6 & $1 / 60$ & 68.9 \\
\hline & 7 & $1 / 60$ & 48.8 \\
\hline & 8 & $0 / 60$ & 57.2 \\
\hline
\end{tabular}

${ }^{* 1}$ See Table 1 for egg treatment protocol.

${ }^{* 2}$ No. positive/No. examined (\%).

intra-ovum infections ranged from 2\% (1/60)-18\% $(11 / 60)$. In lots \#6 and \#7, where the challenged eggs were immediately inseminated and water-hardened in povidone-iodine, the prevalence of intra-ovum infections ranged from $0-3 \%(2 / 60)$. F. psychrophilum was not detected in the unchallenged controls (lot \#8). The challenged and treated egg lots displayed eyed-egg rates as high as those of unchallenged control egg lots.

\section{The efficacy of povidone-iodine treatments in preventing} transmission to fry

When the challenged coho salmon eggs were disinfected with povidone-iodine prior to fertilization (lot \#1-\#5), no F. psychrophilum was isolated from fry at moribund state as well as the eyed-eggs (Table 3). In 
Table 3. Detection of Flavobacterium psychrophilum from eggs and subsequent fry of coho salmon after povidone-iodine treatments

\begin{tabular}{|c|c|c|c|c|c|c|c|c|}
\hline \multicolumn{5}{|c|}{ Experiment group } & \multirow[b]{2}{*}{$\begin{array}{l}\text { Intra-ovum } \\
\text { infection } \\
\text { rate }\end{array}$} & \multirow[b]{2}{*}{$\begin{array}{l}\text { Hatching } \\
\text { rate }(\%)\end{array}$} & \multirow[b]{2}{*}{$\begin{array}{c}\text { Fish } \\
\text { survival } \\
\text { rate (\%) in } \\
\text { six } \\
\text { months }\end{array}$} & \multirow[b]{2}{*}{$\begin{array}{c}\text { Detection of } \\
\text { F. psychrophilum } \\
\text { from moribund } \\
\text { fish }\end{array}$} \\
\hline Lot No. & $\begin{array}{l}\text { Immersion } \\
\text { challenge of } \\
\text { eggs with } \\
\text { F. psychrophilum }\end{array}$ & $\begin{array}{l}\text { Egg treatment } \\
\text { prior to } \\
\text { fertilization with }\end{array}$ & $\begin{array}{l}\text { Water-hardening of } \\
\text { eggs ( } 45 \mathrm{~min}) \text { with }\end{array}$ & $\begin{array}{l}\text { Disinfection of } \\
\text { water-hardened } \\
\text { eggs with } \\
\text { povidone-iodine } \\
\text { (50 ppm, } 15 \mathrm{~min} \text { ) }\end{array}$ & & & & \\
\hline 1 & Yes & $\begin{array}{l}\text { Povidone-iodine } \\
\text { (50 ppm) }\end{array}$ & $\begin{array}{l}\text { povidone-iodine } \\
\text { (50 ppm) }\end{array}$ & Yes & $0 / 60 *$ & 98 & 95 & $0 / 1^{*}$ \\
\hline 2 & Yes & $\begin{array}{l}\text { Povidone-iodine } \\
\text { (50 ppm) }\end{array}$ & $\begin{array}{l}\text { povidone-iodine } \\
\text { (100 ppm) }\end{array}$ & Yes & $0 / 60$ & 100 & 95 & $0 / 5$ \\
\hline 3 & Yes & $\begin{array}{l}\text { Povidone-iodine } \\
\text { (50 ppm) }\end{array}$ & $\begin{array}{l}\text { povidone-iodine } \\
\text { (150 ppm) }\end{array}$ & Yes & $0 / 60$ & 100 & 94 & $0 / 10$ \\
\hline 4 & Yes & $\begin{array}{l}\text { Povidone-iodine } \\
\text { (50 ppm })\end{array}$ & $\begin{array}{l}\text { povidone-iodine } \\
\text { ( } 200 \mathrm{ppm})\end{array}$ & Yes & $0 / 60$ & 98 & 97 & $0 / 3$ \\
\hline 5 & Yes & $\begin{array}{l}\text { Povidone-iodine } \\
\text { (50 ppm) }\end{array}$ & Water & Yes & $0 / 60$ & 99 & 97 & $0 / 3$ \\
\hline 6 & Yes & PBS & Water & Yes & $0 / 60$ & 99 & 92 & $4 / 12$ \\
\hline 7 & Yes & No & Water & Yes & $1 / 60$ & 99 & 93 & $5 / 11$ \\
\hline 8 & No & No & Water & Yes & $0 / 60$ & 100 & 79 & 0/22 \\
\hline
\end{tabular}

* No. positive/No. examined (\%)

contrast, F. psychrophilum was isolated from $1.7 \%(1 / 60)$ of eyed-eggs and $45 \%(5 / 11)$ of subsequent moribund fry in lots in which the challenged eggs were immediately inseminated without disinfection with povidoneiodine (lot \#7). In addition, when the challenged eggs were rinsed with PBS instead of iodine prior to fertilization (lot \#6), F. psychrophilum was isolated from $33 \%$ (4/12) of fry, but not from eyed-eggs. The hatching rates in each lot were greater than $98 \%$, and the survival rates were more than $90 \%$ except for the unchallenged control lot in which the fry died due to failure in getting them to eat.

\section{Discussion}

In the first experiment, where newly spawned unfertilized eggs were immersion-challenged with $F$. psychrophilum and subsequently inseminated and water-hardened without any disinfection process, the bacteria were detected in the egg contents at a high prevalence. When the challenged eggs were disinfected with povidone-iodine (50 ppm, $15 \mathrm{~min}$ ) prior to fertilization, intra-ovum infection was not detected. Without this pre-fertilization disinfection with povidoneiodine, however, a disinfection procedure, i.e. waterhardening of challenged eggs in povidone-iodine (50-100 ppm) was insufficient to prevent the intra-ovum infection. In Atlantic salmon hatcheries in the USA, where fertilized eggs are water-hardened in povidoneiodine $(50 \mathrm{ppm})$ without disinfection by iodine prior to insemination, it was noted that intra-ovum infection occurred in the eggs (Cipriano, 2005). Thus, the findings in the present study are consistent with those from Atlantic salmon hatcheries. A few F. psychrophilum cells might passively enter the perivitelline space in the process of water hardening, resulting in intra-ovum infection (Kumagai and Nawata, 2010). Since the bactericidal activity of iodine might be reduced by the presence of organic materials in the perivitelline space, the disinfectant is not effective to kill all bacteria in the perivitelline space during water hardening. Therefore, the surface disinfection of unfertilized eggs prior to insemination was essential in preventing intra-ovum infection.

The first experiment also showed that rinsing the surface-contaminated eggs three times with five volumes of PBS instead of iodine prior to insemination was ineffective in preventing intra-ovum infection. In our previous study ${ }^{* 1}$, the concentration $\left(>10^{9} \mathrm{CFU} / \mathrm{mL}\right)$ of $F$. psychrophilum contaminating the egg surface was reduced only 1,000-fold by rinsing three times with five volumes of PBS. On the other hand, intra-ovum infection occurred in unfertilized eggs where the surface was contaminated with bacteria at concentrations higher than $10^{6} \mathrm{CFU} / \mathrm{mL}$ (Kumagai and Nawata, 2010). Therefore, the volume of PBS used for the rinse in the experiment appeared to be insufficient to reduce the bacterial concentration to lower than $10^{6} \mathrm{CFU} / \mathrm{mL}$. Although this rinse procedure using isotonic sodium solution has been practiced in many salmonid hatcheries in Japan to increase the fertilization rate, it would appear that it is difficult to prevent intra-ovum infection using only the rinse procedure.

In the second experiment, povidone-iodine treat-

\footnotetext{
*1 Kumagai, A. and A. Nawata (2009): Prevention of Flavobacterium psychrophilum vertical transmission in salmonids. Annual Report of Japan Fisheries Resource Conservation Association, pp. 27-40. (in Japanese)
} 
ment of surface-contaminated unfertilized eggs was found to be effective in controlling both intra-ovum infection and transmission to fry. F. psychrophilum was not isolated from moribund fry originating from the intraovum infection negative lots, in which the challenged eggs were disinfected with povidone-iodine prior to fertilization (lots \#1-\#5). In contrast, bacteria were vertically transmitted to fry via the egg contents in the intraovum infection positive lot (lot \#7). Additionally, when the challenged eggs were rinsed with PBS without disinfection prior to insemination, F. psychrophilum was isolated from moribund fry (lot \#6), confirming that the rinse procedure is ineffective in completely preventing vertical transmission.

In the first and second experiments, all egg lots where the povidone-iodine treatments of eggs, i.e. the pre-fertilization disinfection with povidone-iodine (50 ppm) and water-hardening of eggs in povidone-iodine (50-200 ppm), displayed eyed-egg rates as high as those of untreated control egg lots. These results indicate that the povidone-iodine treatments do not affect the survival of eggs.

In the present study, we demonstrated that the povidone-iodine treatment of contaminated unfertilized eggs, particularly pre-fertilization disinfection, was an effective means of controlling intra-ovum infection and vertical transmission to fry. F. psychrophilum has been detected in milt as well as ovarian fluid of salmonids (Holt et al., 1993). However, since the viable bacterial counts in milt were lower $\left(<10^{4} \mathrm{CFU} / \mathrm{mL}\right)$ than in ovarian fluid $^{* 2}$, it is thought that the bacteria derived from milt can not effectively invade the eggs. We therefore conclude that the pre-fertilization disinfection procedure is a promising method for preventing the vertical transmission of BCWD.

*2 Kumagai, A. and A. Nawata (2008): Prevention of Flavobacterium psychrophilum vertical transmission in salmonids. Annual Report of Japan Fisheries Resource Conservation Association, pp. 203-215. (in Japanese)

\section{Acknowledgements}

We are grateful to Dr. T. Yoshinaga (The University of Tokyo) who kindly reviewed the manuscript. This study was supported by grants from the Ministry of Agriculture, Forestry, and Fisheries of Japan and from Miyagi Prefectural Government.

\section{References}

Aoshima, S. (2007): Disease problems of cultured salmonids in Japan derived from diagnostic records at prefectural fisheries experimental stations from 1978 to 2002. Fish Pathol., 42, 119-122. (in Japanese with English abstract)

Bernardet, J. F. and B. Kerouault (1989): Phenotypic and genomic studies of 'Cytophaga psychrophila' isolated from diseased rainbow trout (Oncorhynchus mykiss) in France. Appl. Environ. Microbiol., 55, 1796-1800.

Brown, L. L., W. T. Cox and R. P. Levine (1997): Evidence that the causal agent of bacterial cold-water disease Flavobacterium psychrophilum is transmitted within salmonid eggs. Dis. Aquat. Org., 29, 213-218.

Cipriano, R. C. (2005): Intraovum infection caused by Flavobacterium psychrophilum among eggs from captive Atlantic salmon broodfish. J. Aquat. Anim. Health, 17, 275-283.

Holt, R. A., J. S. Rohovec and J. L. Fryer (1993): Bacterial coldwater disease. In "Bacterial diseases of fish" (ed. by V. Inglis, R. J. Roberts and N. R. Bromage). Blackwell Sci. Publ., London, pp. 3-22.

Kumagai, A., K. Takahashi, S. Yamaoka and H. Wakabayashi (1998): Ineffectiveness of iodophore treatment in disinfecting salmonid eggs carrying Cytophaga psychrophila. Fish Pathol., 33, 123-128.

Kumagai, A. and A. Nawata (2010): Mode of the intra-ovum infection of Flavobacterium psychrophilum in salmonid eggs. Fish Pathol., 45, 31-36.

Lorenzen, E. and N. Karas (1992): Detection of Flexibacter psychrophilus by immunofluorescence in fish suffering from fry mortality syndrome: a rapid diagnostic method. Dis. Aquat. Org., 13, 231-234.

Nematollahi, A., A. Decostere, F. Pasmans and F. Haesebrouck (2003): Flavobacterium psychrophilum infections in salmonid fish. J. Fish Dis., 26, 563-574.

Wakabayashi, H., M. Horiuchi, T. Bunya and G. Hoshiai (1991): Outbreaks of cold-water disease in coho salmon in Japan. Fish Pathol., 26, 211-212. 